\title{
THE INFLUENCE OF LASER BEAM AND AUXINS ON ROOTING OF LEATHERLEAF VIBURNUM (VIBURNUM RHYTIDOPHYLLUM HEMSL.) CUTTINGS
}

\author{
Hanna SZAJSNER ${ }^{1}$, Przemysław BĄBELEWSKI ${ }^{2 *}$ \\ ${ }^{1}$ Department of Genetics, Plant Breeding and Seed Production \\ ${ }^{2}$ Department of Horticulture \\ University of Environmental and Life Sciences Wroclaw \\ Plac Grunwaldzki 24 a, 50-363 Wrocław, Poland \\ Received: November 15, 2013; Accepted: April 13, 2014
}

\begin{abstract}
The aim of this work is to compare the effect of three- and sixfold irradiation with a semiconductor laser beams of $200 \mathrm{~mW}$ power and wavelength equal to $670 \mathrm{~nm}$ and the rooting agent on the percentage and quality of rooted cuttings of leatherleaf viburnum. The most effective for root number and root length was threefold irradiation and for fresh root weight threefold irradiation applied together with the rooting agent.
\end{abstract}

Key words: laser photostimulation, rooting, leatherleaf viburnum

\section{INTRODUCTION}

For rooting of cuttings, number of different horticultural practices has been used. The most common is stimulation of rooting with auxin (Bojarczuk 1997). This method requires a preliminary determination of the type and concentration of auxin. However, the use of auxins has difficulties connected with choosing the optimal auxin type or concentration. Among other practices, irradiation with laser beam was recommended for rooting optimisation (Bąbelewski \& Szajsner 2013).

Laser light, featuring coherence and directionality, has a significant impact on bioenergetic processes in tissues of living organisms (Aladjadjiyan 2007, Chen et al. 2005, Vasilevski 2003). Exposition to low power radiation within relatively short time of irradiation causes a biostimulation, connected with absorption of quantised energy by biologically active compounds (Dobrowolski \& Różanowski 1998, Hernandez et al. 2010). In the literature available so far there are only a few publications concerning the effect of semiconductor laser beams on plant material (Ashrafijou et al. 2010, Michtchenko \& Hernandez 2010).
In order to optimise the process of rooting and to improve the quality of root system, apical cuttings of leatherleaf viburnum (Viburnum rhytidophyllum Hemsl.) were subjected to laser photostimulation with the use of diversified doses of semiconductor laser beams, separately or together with the rooting agent.

\section{MATERIALS AND METHODS}

Greenhouse studies were conducted by independent series in the years 2009 and 2010.

The apical cuttings of leatherleaf viburnum, $6 \mathrm{~cm}$ long, were collected from 5-year-old shrubs on 15th July 2009 and 2010. The lower parts of the cuttings were three- (D3) or six- (D6) times irradiated ( 2 minutes intervals between successive irradiations) with semiconductor laser beams of $200 \mathrm{~mW}$ power and wavelength equal to $670 \mathrm{~nm}$ separately or together with application of rooting agent (Ukorzeniacz $\mathrm{AB}$, Himal, Poland) containing $0.3 \%$ NAA, $0.05 \%$ IBA and $5.0 \%$ activated carbon (AB). The model CTL - MX 1106 coupled with a laser scanner cooperating model CTL $1202 \mathrm{~S}$ was used. The rooting agent was also applied separately. 
Control cuttings did not receive rooting agent or irradiation. After irradiation and/or dipping the lower parts of the cuttings in the rooting agent, cuttings were placed in multipot palettes $40 \times 30 \mathrm{~cm}$, filled with the mixture of high-moor peat and perlite $(1: 1 \mathrm{v} / \mathrm{v})$.

Following are the treatments used:

1. (C) - control,

2. (AB) - cuttings treated with preparation Ukorzeniacz $\mathrm{AB}$,

3. (D3) - cuttings treated with three irradiation doses of a semiconductor laser,

4. $(\mathrm{D} 3+\mathrm{AB})-$ cuttings treated with three irradiation doses of a semiconductor laser and preparation Ukorzeniacz AB,

5. (D6) - cuttings treated with six irradiation doses of a semiconductor laser,

6. $(\mathrm{D} 6+\mathrm{AB})-$ cuttings treated with six irradiations doses of a semiconductor laser and preparation Ukorzeniacz AB.

The experiment was repeated year after year. Each combination consisted of four replications of 10 cuttings. Rooting was evaluated after 3 months, and the percentages of rooted cuttings were calculated and the fresh roots weight of cuttings, as well

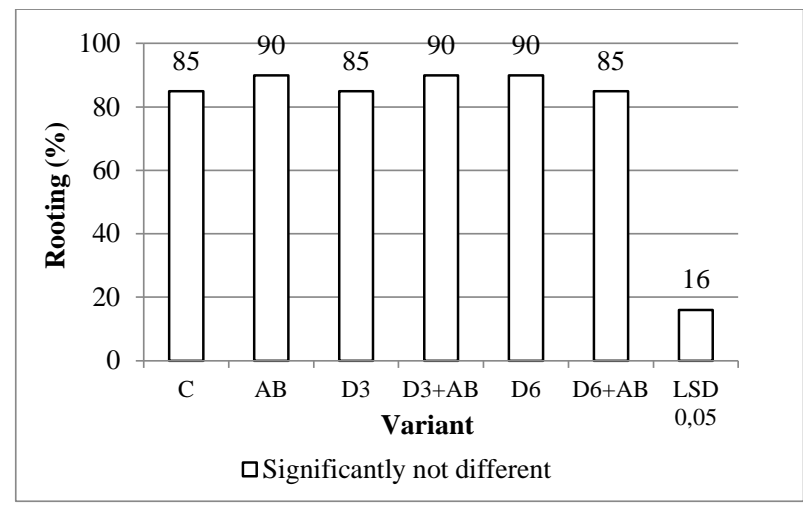

Fig. 1. The influence of the laser light and the rooting preparation on the rooting percentage of leatherleaf viburnum cuttings. $\mathrm{C}$ - control, $\mathrm{AB}$ - rooting preparation, D3 $-3 \mathrm{x}$ irradiation, D6 $-6 \mathrm{x}$ irradiation. Data are means of 2009-2010 years as the number and length of roots were scored. Statistical calculations were made by ANOVA method. Obtained results were analysed according to Duncan's test, at a significance level $p=0.05$. Due to the insignificant differences between years, data were averaged.

\section{RESULTS}

The laser irradiation and the rooting agent $\mathrm{AB}$ did not affect percentage of rooted cuttings that amounted from 85 to $90 \%$ (Fig. 1).

Triple irradiation of cuttings enhanced number of roots to 31.1 in comparison to 25.7 in control. Six-fold irradiation reduced root number to 21.7 (Fig. 2).

Length of roots was stimulated by three- and six-time irradiation alone or together with rooting preparation $(11.8,10.0$ and $10.7 \mathrm{~cm}$, respectively) in comparison with control $(7.4 \mathrm{~cm})$ (Fig. 3).

Three times irradiation or application of rooting agent increased fresh weight of roots to 1.3 and $1.4 \mathrm{~g}$, respectively in comparison with $1.0 \mathrm{~g}$ in control (Fig. 4).

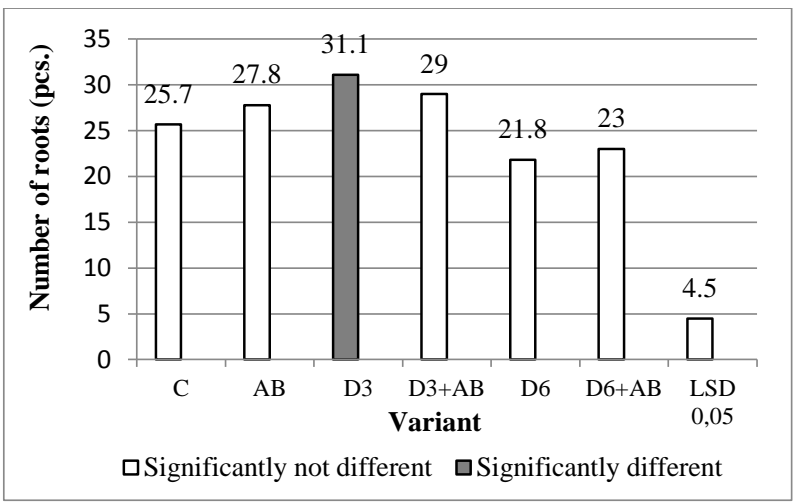

Fig. 2. The influence of the laser light and the rooting preparation on the number of roots of leatherleaf viburnum cuttings. Other explanation see Fig. 1. 


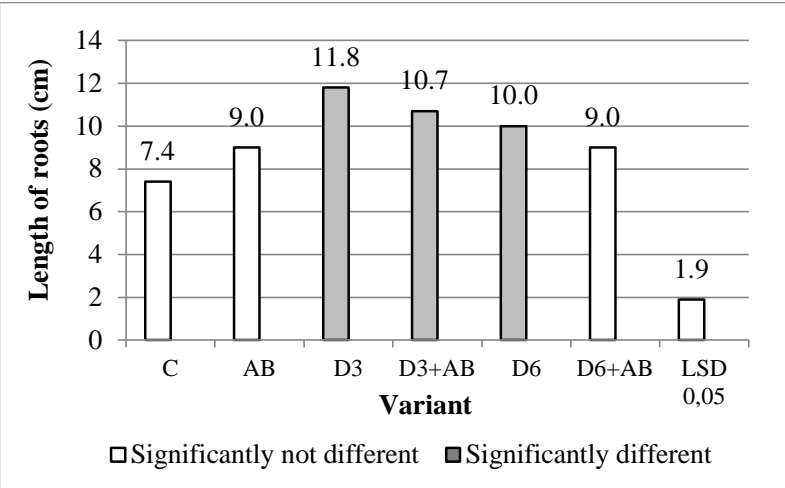

Fig. 3. The influence of the laser light and the rooting preparation on the length of adventitious roots of the leatherleaf viburnum cuttings. Other explanation see Fig. 1.

\section{DISCUSSION}

Improvement of rooting can be achieved through the increase in the percentage of rooted cuttings, number, length and fresh weight of adventitious roots. The first factor taken into account is the type and concentration of auxin. Yet not all species and varieties respond in the same way to auxin treatments (Bojarczuk 1997; Pacholczak et al. 2012). It was reported that laser irradiation on caryopses of wheat, rye and triticale significantly increases indoleacetic acid (IAA) content. Therefore, laser light can be taken as a factor influencing the process of rhizogenesis (Szajsner 2009). If laser stimulation will cause similar changes in content of IAA in cuttings, in turn its usage can results in better rooting. Our results from experiment on laser light and rooting agent application proved favourable effect of threefold irradiation on the number, length and roots fresh weight of leatherleaf viburnum cuttings. The number of roots in irradiated cuttings increased by $21.2 \%$ in relation to control cuttings, and by $11.9 \%$ in relation to cuttings treated with auxin what confirms results of Śliwka and Jakubiak (2007) who obtained higher density of roots, better branching and higher biomass of willow cuttings (Salix viminalis L. 'Turbo') due to laser light application. Kralik and Rauscherova (1990) observed markedly positive effect of laser light on roots length in Ligustrum vulgare L.

In our experiment, cuttings treated with three laser doses were longer by $59 \%$ in comparison with control and by $31 \%$ in comparison with treatment

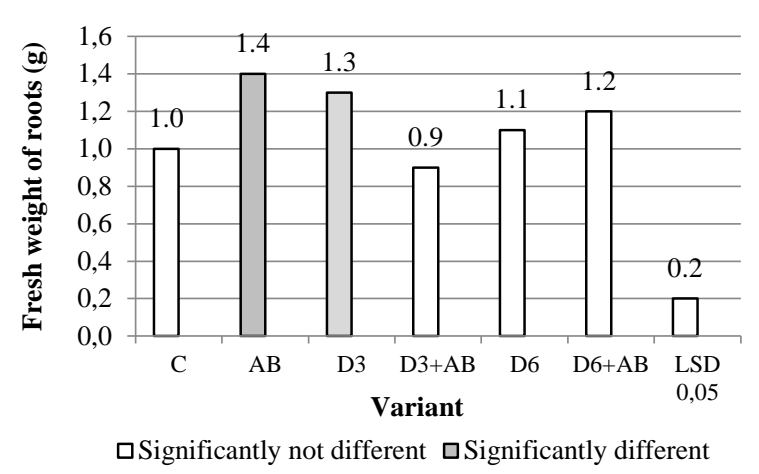

Fig. 4. The influence of the laser light and the rooting preparation on the fresh weight of roots of leatherleaf viburnum cuttings. Other explanation see Fig. 1.

with auxin preparation. Rooting preparation containing NAA and IBA significantly affected only fresh weight of roots by $40 \%$ in comparison to control. Dirr and Heuser (1987) recommended rooting of leatherleaf viburnum with the use of IBA and NAA.

During the experiment, size of leaves were not reduced. According to results obtained by Costa and Challa (2002), we can suppose that applied laser radiation could contribute to the increased auxins content in rooted cuttings. Costa and Challa (2002) stated that increased biomass of cuttings could positively affect the occurrence of adventitious roots. The large surface of leaves in rose cuttings was a good indicator of roots' growth, while reduction in leaf surface features a negative impact. In our study, leaves of viburnum cuttings were not reduced due to the effect of irradiation, what could be a good marker of effective rooting.

We can conclude that triple irradiation of viburnum cuttings can replace use of rooting agent enhancing number and length of roots and their fresh weight.

\section{REFERENCES}

Aladjadjiyan A. 2007. The use of physical methods for plant growing stimulation in Bulgaria. J. Cent. Eur. Agric. 8(3): 369-380.

Ashrafijou A., Sadat Noori S.A., Izadi Darbandi A., Saghafi S. 2010. Effect of salinity and radiation on proline accumulation in seeds of canola (Brassica napus L.). Plant Soil Environ. 56(7): 312-317. 
Bąbelewski P., Szajsner H. 2013. Wpływ promieniowania laserowego na ukorzenianie sadzonek pędowych $\mathrm{u}$ wybranych odmian Chamaecyparis pisifera (Siebold \& Zucc.) Endl. Biologia i ekologia roślin drzewiastych. Materiały z Konf. Nauk. połączonej z obchodami Jubileuszu 80-lecia Instytutu Dendrologii PAN w Kórniku, red. Tomaszewski D., Jagodziński A.M.: 99-100. [in Polish]

Bojarczuk K. 1997. Regulatory roślinne w szkółkarstwie. W: Regulatory wzrostu i rozwoju roślin - tom 2 . Zastosowanie w ogrodnictwie, rolnictwie, leśnictwie i w kulturach tkanek. Jankiewicz L. (red.), PWN Warszawa: 137-165. [in Polish]

Chen Y.P., Yue M., Wang X.L. 2005. Influence of He-Ne laser irradiation on seeds thermodynamic parameters and seedlings growth of Isatis indogotica. Plant Sci. 168(3): 601-606. DOI: 10.1016/j.plantsci.2004.09.005.

Costa J. M., Challa H. 2002. The effect of the original leaf area on growth of softwood cuttings and planting material of rose. Sci. Hortic. 95(1-2): 111-121. DOI: 10.1016/S0304-4238(02)00023-7

Dirr M.A., Heuser Ch.W. 1987. The reference manual of woody plant propagation: from seed to tissue culture. Varsity Press, Inc. Athens Georgia (USA), p. 232.

Dobrowolski J.W., Różanowski B. 1998. The influence of laser light on accumulation of selected macro-, trace- and ultra-elements by some plants. Mengenund Spurenelemente, Fridrich-Schiler - Universität Jena, pp. 147-156.
Hernandez A.C., Dominquez P.A., Cruz O.A., Ivanov R., Carballo C.A., Zepeda B.R. 2010. Laser in agriculture. Int. Agrophys. 24(4): 407-422.

Kralik J., Rauscherova L. 1990. Effect of laser irradiation on rhizogenes cuttings Ligustrum vulgare L. Forestry 36(LXIII): 241-244. [in Czech]

Michtchenko A., Hernández M. 2010. Photobiostimulation of germination and early growth of wheat seeds (Triticum aestivum L.) by a $980 \mathrm{~nm}$ semiconductor laser. Rev. Cub. Fis. 27(2B): 271-274.

Pacholczak A., Szydło W., Jacygrad E., Federowicz M. 2012. Effect of auxins and the biostimulator algaminoplant on rhizogenesis in stem cuttings of two dogwood cultivars (Cornus alba 'Aurea' and 'Elegantissima'). Acta Sci. Pol., Hortorum Cultus 11(2): 93-103.

Szajsner H. 2009. The analysis of laser radiation treatment effects on grains of selected genotypes of cereals. Zesz. Nauk. Uniwersytetu Przyrodniczego we Wrocławiu nr 571, Rozprawy CCLVI, 99 p. [in Polish with English abstract]

Śliwka M., Jakubiak M. 2007. Wpływ stymulacji laserowej na zwiększenie przyrostu biomasy oraz zdolności bioremediacyjnych roślin wykorzystywanych w hydrofitowych oczyszczalniach ścieków. Ochrona Środowiska i Zasobów Naturalnych 33: 103-107. [in Polish]

Vasilevski G. 2003. Perspectives of the application of biophysical methods in sustainable agriculture. Bulg. J. Plant Physiol, Special Issue, pp. 179-186. 